\title{
Pola Kuman dan Sensitifittas Antibiotik di Ruang Perinatologi
}

\section{Made Kardana}

Bagian Ilmu Kesehatan Anak, Fakultas Kedokteran Universitas Udayana, RSUP Sanglah, Denpasar

\begin{abstract}
Latar belakang. Penggunaan antibiotik pada sepsis neonatorum seharusnya didasarkan pada kuman penyebab infeksi yang diperoleh dari biakan darah dan hasil uji sensitifitas. Pola kuman dan hasil uji sensitifitas dapat dipakai sebagai dasar pemberian antibiotik secara empiris.

Tujuan. Mengetahui profil mikroorganisme penyebab sepsis neonatorum di Bagian Ilmu Kesehatan Anak RSUP Sanglah Denpasar serta sensitifitasnya terhadap antibiotik.

Metode. Penelitian retrospektif dilakukan dari Januari 2008-Desember 2009. Kriteria inklusi adalah neonatus tersangka sepsis dan didiagnosis akhir sebagai sepsis neonatorum berdasarkan biakan darah positif. Kriteria eksklusi apabila data tidak lengkap.

Hasil. Terdapat 458 kasus tersangka sepsis. Biakan darah positif 220 (48\%). Bakteri penyebab terbanyak adalah Serratia marcescens. Bakteri penyebab sepsis mempunyai sensitifitas rendah terhadap antibiotik lini pertama (ampisilin dan gentamisin), kecuali Acinetobacter baumannii mempunyai sensitifitas tinggi terhadap antibiotik tersebut. Sensitifitas bakteri penyebab sepsis umumnya masih tinggi terhadap meropenem, cefoperason-sulbactam, dan piperasilin-tazobactam.

Kesimpulan. Penyebab sepsis neonatorum terbanyak adalah Serratia marsescens. Sebagian besar bakteri penyebab sepsis mempunyai sensitifitas rendah terhadap ampisilin dan gentamisin, kecuali Acinetobacter baumannii. Terhadap meropenem, cefoperazon-sulbactam dan piperasilin-tazobactam sensitifitas masih tinggi. Sari Pediatri 2011;12(6):381-5.
\end{abstract}

Kata kunci: pola kuman, sensitifitas, antibiotik

\section{Alamat korespondensi:}

Dr. I Made Kardana, Sp.A. Bagian Ilmu Kesehatan Anak, Fakultas Kedokteran Universitas Udayana, RSUP Sanglah Denpasar. Jl. Pulau Nias 80114. Telp/Fax. (0361) 244038 atau (0361) 257387, E-mail: made_kardana@yahoo.com

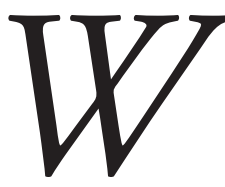

orld Health Organization (WHO) memperkirakan setiap tahun terdapat 130 juta bayi baru lahir di seluruh dunia, dan diperkirakan 4 juta bayi meninggal pada usia empat minggu pertama kehidupan. Penyebab kematian neonatal adalah kelahiran kurang bulan (28\%), infeksi (26\%), asfiksia 
(23\%), kelainan kongenital (7\%), dan penyebab lain (7\%). ${ }^{1-3}$ Berdasarkan data WHO tersebut tampak angka mortalitas bayi yang disebabkan oleh sepsis masih tinggi. Prevalensi sepsis neonatorum di RSUP Sanglah selama tahun 2004 adalah 5,3\%. ${ }^{4}$

Penyebab sepsis neonatorum berbeda antar negara maupun antar waktu, ${ }^{5-6}$ dapat disebabkan oleh bakteri, virus, jamur, dan protozoa. ${ }^{7-8}$ Penggunaan antibiotik pada sepsis neonatorum seharusnya didasarkan pada bakteri penyebab infeksi berdasarkan hasil biakan darah dan uji sensitifitas, ${ }^{5,6,8}$ akan tetapi sampai saat ini pemeriksaan biakan dan uji sensitifitas memerlukan waktu yang lama, sehingga pada kasus tersangka sepsis harus diberikan antibiotik secara empiris. ${ }^{6,9}$ Tujuan penelitian untuk mengetahui profil penyebab sepsis neonatorum di Bagian Ilmu Kesehatan Anak RSUP Sanglah Denpasar serta sensitifitas terhadap antibiotik.

\section{Metode}

Telah dilakukan penelitian retrospektif, dengan mengambil data dari catatan medik pasien. Jumlah sampel adalah semua neonatus yang dirawat dengan tersangka sepsis dan terbukti biakan darah positif. Penelitian dilakukan di ruang rawat sub-bagian Perinatologi Bagian Ilmu Kesehatan Anak RSUP Sanglah Denpasar, dari 1 Januari 2008-31 Desember 2009. Kriteria inklusi (1) Neonatus tersangka sepsis dan hasil biakan darah positif. Kriteria tersangka sepsis sesuai dengan protokol sub-bagian Perinatologi Bagian IKA RSUP Sanglah, yaitu berdasarkan gejala klinis, septic marker yaitu hitung leukosit, hitung trombosit, rasio IT (rasio imatur/total neutrofil), dan CRP (C-reactive protein). Kriteria eksklusi apabila data tidak lengkap. Data diolah dengan program komputer, disajikan dalam bentuk tabel dan naratif. Penelitian telah mendapat kelayakan etik dari Komite Etik penelitian FK UNUD/RSUP Sanglah Denpasar.

\section{Hasil}

Terdapat 458 neonatus tersangka sepsis neonatorum dengan 220 (48\%) biakan darah positif. Ditemukan 19 kasus mempunyai data tidak lengkap. Delapan biakan darah positif terhadap candida albicans, dan 193 biakan darah positif bakteri.
Sebagian besar pasien adalah laki-laki $(60,1 \%)$, umur kehamilan terbanyak adalah 37-42 minggu (63\%). Sebagian besar (64\%) lahir spontan, berat badan lahir terbanyak (55,2\%) 2500-3999 gram, dan sebagian besar bayi lahir mengalami asfiksia. (Tabel 1)

Tabel 1. Karakteristik subyek

\begin{tabular}{|c|c|c|}
\hline Karakteristik & Jumlah (n) & $\%$ \\
\hline \multicolumn{3}{|l|}{ Jenis kelamin } \\
\hline Laki-laki & 112 & 60,1 \\
\hline Perempuan & 81 & 39,3 \\
\hline \multicolumn{3}{|l|}{ Cara persalinan } \\
\hline Spontan & 130 & 64 \\
\hline Seksio sesaria & 67 & 33 \\
\hline Vakum ekstraksi & 4 & 2 \\
\hline Forseps ekstraksi & 2 & 1 \\
\hline \multicolumn{3}{|l|}{ Keadaan lahir } \\
\hline Vigerous baby & 95 & 49,2 \\
\hline Asfiksia sedang & 45 & 23,3 \\
\hline Asfiksia berat & 53 & 27,5 \\
\hline \multicolumn{3}{|c|}{ Berat badan lahir (gram) } \\
\hline$<1000$ & 2 & 1,0 \\
\hline 1000-1499 & 13 & 6,4 \\
\hline $1500-2499$ & 70 & 34,4 \\
\hline $2500-3999$ & 112 & 55,2 \\
\hline$\geq 4000$ & 6 & 3,0 \\
\hline \multicolumn{3}{|c|}{ Umur kehamilan (minggu) } \\
\hline$<28$ & 2 & 1,0 \\
\hline $28-32$ & 31 & 15,3 \\
\hline $33-36$ & 42 & 20,7 \\
\hline $37-42$ & 128 & 63 \\
\hline$>42$ & 0 & 0 \\
\hline
\end{tabular}

Bakteri penyebab sepsis didominasi oleh bakteri gram negatif (68,3\%), terbanyak adalah Serratia marcescens $(23,5 \%)$. Bakteri gram positif proporsinya hanya 31,7\% terdiri dari Staphylococcus coagulase positive (16,4\%), Staphylococcus coagulase negative (10,2\%), dan Streptococcus viridans (4,6\%). (Tabel 2)

Sebagian bakteri penyebab sepsis neonatorum mempunyai sensitifitas yang rendah terhadap antibiotik lini pertama (ampisilin, gentamisin), dan antibiotik lini ke-dua (sefotaksim dan seftasidim), kecuali Acinetobacter baumannii masih mempunyai sensitifitas tinggi. Sensitifitas tinggi tampak pada antibiotik meropenem, piperasilin-tazobaktam, sefoperazon-sulbaktam, siproflosaksin, dan fosfomisin (Tabel 3). 
Tabel 2. Jenis bakteri penyebab sepsis neonatorum

\begin{tabular}{|c|c|c|c|c|}
\hline \multirow{2}{*}{ Jenis bakteri } & \multicolumn{2}{|c|}{ Awitan Sepsis } & \multirow{2}{*}{$\begin{array}{l}\text { Jumlah } \\
\text { (n) }\end{array}$} & \multirow{2}{*}{$\%$} \\
\hline & $\operatorname{Dini}(\mathrm{n})$ & Lambat (n) & & \\
\hline Serratia marcescens & 40 & 6 & 46 & 23.5 \\
\hline Staphylococcuss coagulase positive & 26 & 4 & 32 & 16.4 \\
\hline Staphylococcuss coagulase negative & 16 & 5 & 21 & 10.7 \\
\hline Enterobacter sp. & 17 & 3 & 20 & 10.2 \\
\hline Klebsiella pneumoniae & 14 & 2 & 16 & 8.2 \\
\hline Acinetobacter baumannii & 11 & 4 & 15 & 7.6 \\
\hline Flavimonas oryzihabitans & 12 & 2 & 14 & 7.1 \\
\hline Pseudomonas sp & 12 & 1 & 13 & 6.6 \\
\hline Streptococcus viridans & 8 & 1 & 9 & 4.6 \\
\hline Serratia liquefaciens & 4 & 0 & 4 & 2.0 \\
\hline Pantoea sp. & 2 & 1 & 3 & 1.5 \\
\hline Eschericia coli & 1 & 0 & 1 & 0.5 \\
\hline Rautella ferrigenis & 1 & 0 & 1 & 0.5 \\
\hline Hafnia alvei & 1 & 0 & 1 & 0.5 \\
\hline Providencia stuartii & 1 & 0 & 1 & 0.5 \\
\hline Jumlah & 166 & 29 & 195 & 100 \\
\hline
\end{tabular}

Tabel 3, Pola sensitifitas bakteri terhadap antibiotik

\begin{tabular}{|c|c|c|c|c|c|c|c|c|c|c|}
\hline \multirow[b]{2}{*}{ Antibiotik } & \multicolumn{10}{|c|}{ Jenis kuman (\%) } \\
\hline & 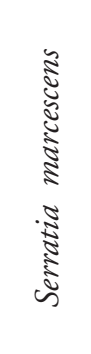 & 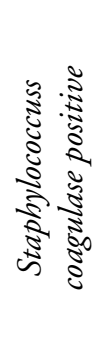 & 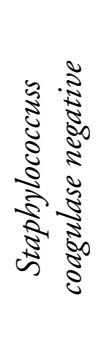 & 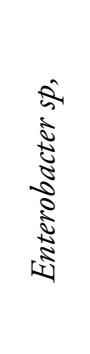 & 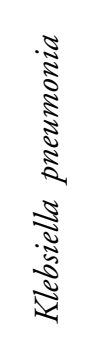 & 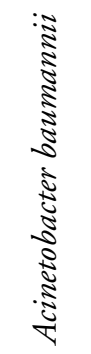 & 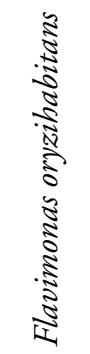 & $\begin{array}{l}5 \\
5 \\
5 \\
5 \\
5 \\
5 \\
5 \\
5 \\
5 \\
5\end{array}$ & 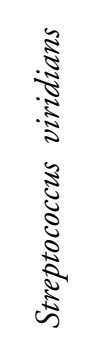 & 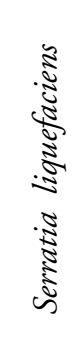 \\
\hline Ampisilin & 50 & 27,3 & 44,4 & 0 & 45,2 & 87,5 & 25 & 50 & 42,9 & - \\
\hline Gentamisin & 5,9 & 50 & 57,1 & 46,7 & 7,7 & 92,9 & 46,7 & 33,3 & 25 & 33,3 \\
\hline Sefotaksim & 42,9 & 60 & 50 & 50 & 30 & 50 & 60 & 50 & 75 & 0 \\
\hline Ceftasidim & 45,2 & 5,9 & 31,3 & 50 & 18,2 & 81,8 & 63,6 & 45,5 & 14,3 & 0 \\
\hline Fosfomisin & 63,6 & 53,3 & 87,5 & 100 & 75 & 25 & 14,3 & 33,3 & 100 & 50 \\
\hline Meropenem & 91,7 & 100 & 87,5 & 66,7 & 100 & 72,7 & 100 & 66,7 & 100 & 100 \\
\hline Siproflosaksin & 26,7 & 52,4 & 57,9 & 78,9 & 92,9 & 77,8 & 85,7 & 90 & 83,3 & 0 \\
\hline Piperasilin & 80 & 71,4 & 61,5 & 100 & 100 & 57,1 & 83,3 & 80 & - & - \\
\hline kloramfenikol & 92,6 & 18,8 & 53,8 & 60 & 91,7 & 20 & 63,6 & 25 & 25 & 100 \\
\hline Sefoperason & 71,4 & 50 & 73,3 & 87,5 & 60 & 50 & 60 & 100 & - & 100 \\
\hline
\end{tabular}




\section{Pembahasan}

Biakan darah positif terdapat pada $48 \%$ subyek, hampir sama dengan data dari RS Cipto Mangunkusumo Jakarta $41,2 \%,{ }^{10}$ dan di Iran 41\%. ${ }^{11}$ Kemungkinan hasil biakan steril disebabkan oleh pemberian antibiotik profilaksis pada ibu hamil dan bayi baru lahir, pemberian antibiotik sebelum biakan darah diambil, volume pengambilan contoh darah terlalu sedikit, dan mungkin sepsis disebabkan oleh virus atau bakteri anaerob yang sulit tumbuh. ${ }^{6,10}$

Bakteri gram negatif sebagai penyebab sepsis pada penelitian kami jauh lebih tinggi dibandingkan bakteri gram positif (68,3\% versus 31,7\%). Penelitian sebelumnya di rumah sakit Sanglah oleh Suarca dkk, ${ }^{4}$ mendapatkan bakteri penyebab sepsis neonatorum didominasi oleh bakteri gram negatif yaitu Enterobacter $s p$, dan Klebsiella sp. Di RS Cipto Mangunkusumo seperti yang dilaporkan oleh Juniatiningsih $\mathrm{dkk} .{ }^{10}$ mendapatkan Acinetobacter calcoaceticus adalah isolat terbanyak (14,7\%), diikuti Staphylococcus epidermidis (6,9\%), Enterobacter aerogenes (4,9\%). Sedangkan di RS Dr. Moewardi Surakarta bakteri penyebab sepsis terbanyak adalah Enterobacter (42,9\%), ${ }^{12}$ Mayetti dan Imilda ${ }^{13}$ di Padang mendapatkan Staphylococcus aureus $(32,6 \%)$ merupakan penyebab yang terbanyak diikuti oleh Klebsiella sp dan Enterobacter sp (masing-masing $22,6 \%$ ). Trotman $\mathrm{dkk},{ }^{14}$ di Jamaika mendapatkan kuman penyebab sepsis neonatorum berturut-turut adalah Klebsiella pnemoniae (27,6\%), Eschericia coli (16,6\%), dan Enterobacter (10,3\%). Penelitian di Irak mendapatkan penyebab sepsis neonatorum terbanyak adalah Klebsiella pnemoniae (36,6\%), E. coli $(27,5 \%$, dan E. aerugenosa (22,5\%). ${ }^{15}$ Keadaan yang berlawanan didapatkan di negara maju, penyebab sepsis terutama sepsis awitan dini didominasi oleh kuman gram positif. Penelitian di Yale-New Haven Hospital (Y-NHH) mendapatkan penyebab terbanyak sepsis adalah kuman Streptococcus group B (47\%). ${ }^{16}$ Penelitian di Brighan and Women's Hospital Boston mendapatkan penyebab terbanyak sepsis adalah Streptococcus group $B$ (41,5\%, dan E. coli (20,2\%). ${ }^{17}$ Perbedaan pola kuman tersebut kemungkinan disebabkan oleh berbagai hal seperti tingginya insidens kolonisasi kuman pada ibu, perbedaan pola kuman di lingkungan ibu dan bayi, perbedaan respon imun dan faktor genetik dari populasi, perbedaan cara analisis mikrobiologis, perbedaan tingkat pendidikan dan pelayanan kesehatan serta perubahan pola antibiotik dan gaya hidup., $, 6,9$
Kami mendapatkan, bakteri penyebab sepsis mempunyai sensitifitas rendah terhadap antibiotik lini pertama yaitu 0\%-57,1\%, kecuali Acinetobacter baumannii. Sedangkan pada sebagian besar kuman penyebab sepsis mempunyai sensitifitas tinggi terhadap meropenem. Penelitian sebelumnya, Suarca dkk, ${ }^{4}$ juga mendapatkan ampisilin tidak lagi sensitifitas terhadap kuman penyebab sepsis dan gentamisin $(22,2 \%)$. Di RS DR Moewardi Surakarta, dilaporkan sensitifitas terhadap ampisilin adalah Enterobacter (0\%), Staphylococcus (12,5\%), dan Citrobacter (0\%). Sedangkan terhadap gentamisin ketiga bakteri sudah resisten, dan terhadap meropenem mempunyai sensitifitas berturut-turut $73,3 \%, 25 \%$, dan $100 \% .^{12}$ Di RSCM Jakarta, Acinetobacter, bakteri penyebab terbanyak sepsis telah resisten terhadap ampisilin, sensitifitas gentamisin 33,3\%, dan terhadap meropenem $100 \% .{ }^{10}$ Rad dkk, ${ }^{11}$ di Iran mendapatkan Klebsiella sp. bakteri penyebab sepsis terbanyak semuanya resisten terhadap ampisilin, sedangkan dengan meropenem sensitif $100 \%$. Pola sensitifitas antibiotik tampaknya berbeda dalam berbagai laporan penelitian dan pada waktu yang berbeda, kemungkinan disebabkan oleh karena munculnya strain resisten sebagai akibat penggunaan antibiotik yang sembarangan. Tingkat resistensi yang tinggi mungkin juga terkait dengan penggunaan antibiotik tersebut sebagai profilaksis dalam perawatan neonatus di rumah sakit., ${ }^{9,20}$

\section{Kesimpulan}

Penyebab sepsis neonatorum di Bagian Ilmu Kesehatan Anak terbanyak adalah Serratia marsescens. Sensitifitas bakteri gram negatif dan gram positif pada umumnya rendah terhadap antibiotik lini pertama yaitu ampisilin dan gentamisin, kecuali Acinetobacter baumannii. Sedangkan sensitifitas terhadap meropenem, sefoperason-sulbaktam, dan piperasilintazobaktam masih tinggi. Disarankan pemberian antibiotik empirik hendaknya memperhatikan pola kuman setempat. Surveilans bakteri dan pola resistensi harus dilakukan secara rutin untuk menetapkan kebijakan penggunaan antibiotik di masing-masing unit perawatan neonatus.

\section{Daftar pustaka}

1. World Health Organization. The millennium develop- 
ment goals report. Geneva: World Health Organization, 2008 [cited 4 Maret 2010]. Didapat dari: URL: http// www.undp..or.idpubsimdg2004BI IndonesiaMDG_BI Goal4.pdf.

2. Lawn JE, Cousens S, Zupan J. 4 million neonatal deaths: When? where? why? The Lancet 2005;17:9-18.

3. Edmond K, Zaidi A. New approaches to preventing, diagnosing, and treating neonatal sepsis. PLoS Med 2010:7:1-8.

4. Suarca IK, Kardana M, Iswari IS. Blood culture and sensitivity test pattern of early versus late onset sepsis in neonatal ward Sanglah Hospital Denpasar. Disampaikan pada $13^{\text {th }}$ National Congress of Child Health Konika XIII, Bandung, July 4-7, 2005.

5. Amir I, Rundjan L. Pemberian antibiotik secara rasional pada sepsis neonatorum. Dalam: Hegar B, Trihono PP, Ifran EB, penyunting. Update in neonatal infection. Pendidikan kedokteran berkelanjutan Ilmu Kesehatan Anak XLVIII, Departemen Ilmu Kesehatan Anak FK UI/RSCM Jakarta. Jakarta: Departemen Ilmu Kesehatan Anak FKUI-RSCM; 2005. h.32-43.

6. Aminullah A. Masalah terkini sepsis neonatorum. Dalam Hegar B, Trihono PP, Ifran EB, penyunting. Update in neonatal infection. Pendidikan kedokteran berkelanjutan Ilmu Kesehatan Anak XLVIII, Departemen Ilmu Kesehatan Anak FK UI/RSCM Jakarta. Jakarta: Departemen Ilmu Kesehatan Anak FKUI-RSCM; 2005. h.1-16.

7. Stoll BJ. Infections of the neonatal infant. Dalam: Behrman RE, Kliegman RM, Jenson HB, penyunting. Nelson textbook of pediatrics. Edisi ke-18. Philadelphia: WB Saunders; 2007.h.794-811.

8. Puopolo KM. Bacterial and fungal infections. Dalam: Cloherty JP, Eichenwald EC, Stark AR, penyunting. Manual of neonatal care. Edisi ke-6. Philadelphia: Lippincott William \& Wilkins; 2008.h.274-300.
9. Ayoniyi DO, Udo SJ, Oguntibeju OO. An epidemiological survey of neonatal sepsis in a hospital in Western Nigeria. African Journal of Microbiology Research. 2009;3:385-9.

10. Juniatiningsih A, Aminullah A, Firmansyah A. Profil mikroorganisme penyebab sepsis neonatorum di Departemen Ilmu Kesehatan Anak Rumah Sakit Cipto Mangunkusumo Jakarta. Sari Pediatri. 2008;10:60-5.

11. Rad EM, Momtazmanesh. Neonatal sepsis due to klebsiella: frequency, outcome and antibiotic sensitivity. Iranian J Publ Health. 2004;33:43-8.

12. Yulidar H, Martuti S, Sunyataningkamto. Pola kuman, sensitifitas antibiotik dan risiko kematian oleh kuman staphylococcus coagulase negatif pada sepsis neonatorum di RS DR Moewardi Surakarta. Sari Pediatri. 2006;8:122-6.

13. Mayetti, Imilda I. Pola bakteriologis dan uji sensitivitas pada sepsis neonatorum awitan dini. Sari Pediatri. 2010;11:326-9.

14. Trotman H, Bell Y, Thame M, Nicholson AM, Barton M. Predictor of poor outcome in neonates with bacterial sepsis admitted to the University Horpital of the West Indies. West Indian Med J. 2006;55:80-4.

15. Jumah DS, Hassan MK. Predictor of mortality outcome in neonatal sepsis. The Medical Journal of Basrah University (MUBU). 2007;25:11-8.

16. Bizzaro MJ, Raskind C, Baltimore RS, Gallagher PG. Seventy-five years of neonatal sepsis at Yale: 1928-2003. Pediatrics 2005;116:595-602.

17. Puopolo KM, Eichenwald EC. No change in the incidence of ampicillin-resistant, neonatal, early-onset sepsis over 18 years. Pediatrics 2010;125:e1031-8.

18. Vergnano S, Sharland M, Kazembe P, Mwansambo C, Heath PT. Neonatal sepsis: an international perspective. Arch. Dis. Child. Fetal Neonatal Ed. 2005;90;220-4. 